\title{
CLINICAL AND AETIOLOGICAL PATTERN OF VAGINAL DISCHARGE IN PATIENTS ATTENDING STD CLINIC OF A TERTIARY HOSPITAL
}

Venkata Krishna Ananthula1, Prasad J. V. D. S2, Sumana Katikala3, Venkata Ramana Godha ${ }^{4}$, Padmaja Pinjala 5 , Prasad K. N6, Subhash Reddy Dudhipala7, Gautham Krishna Reddy ${ }^{8}$

\begin{abstract}
${ }^{1}$ Associate Professor, Department of Dermatology, Osmania Medical College \& Osmania General Hospital, Hyderabad, Telangana. ${ }^{2}$ Associate Professor, Department of Dermatology, Osmania Medical College \& Osmania General Hospital, Hyderabad, Telangana. ${ }^{3}$ Civil Assistant Surgeon, Department of Dermatology, Osmania Medical College \& Osmania General Hospital, Hyderabad, Telangana. ${ }^{4}$ Professor, Department of Dermatology, Osmania Medical College \& Osmania General Hospital, Hyderabad, Telangana.

${ }_{5}^{5}$ Associate Professor, Department of Dermatology, Osmania Medical College \& Osmania General Hospital, Hyderabad, Telangana. ${ }^{6}$ Assistant Professor, Department of Dermatology, Osmania Medical College \& Osmania General Hospital, Hyderabad, Telangana. ${ }^{7}$ Assistant Professor, Department of Dermatology, Osmania Medical College \& Osmania General Hospital, Hyderabad, Telangana. ${ }^{8}$ Senior Resident, Department of Dermatology, Osmania Medical College \& Osmania General Hospital, Hyderabad, Telangana.
\end{abstract}

\begin{tabular}{l}
\hline ABSTRACT \\
BACKGROUND \\
Vaginal discharge is a considerable problem for many women causing discomfort, anxiety affecting women's quality of life and \\
consuming considerable resources though some vaginal discharges are normal.
\end{tabular}

\section{MATERIALS AND METHODS}

This is a descriptive (Prospective) study undertaken over a period of 12 months in STD Clinic, Dept. of DVL, Osmania Medical College/Osmania General Hospital, Hyderabad. A total of 100 eligible consented women with vaginal discharge in reproductive age group (15-50 yrs.) were studied with consequent sampling methodology with zero intervals after administering inclusion and exclusion criteria. The percentage method is followed for statistics.

\section{RESULTS}

Among the study group of 100, 84 (84\%) women were having pathological vaginal discharge and 16 (16\%) were having the excessive amount physiological discharge. Bacterial Vaginosis (BV) is most common with 51 (51\%), followed by Candidal Vaginitis (CV) in 30 (30\%), Trichomonal Vaginitis (TV) in 18 (18\%) and Mixed infections in 15 (15\%). However, 16 (16\%) women attended with physiological discharge with assumption of pathologic discharge. 44 (44\%) were having risky sexual behaviour of participating in multiple sexual encounters with other than regular partner in the last 30 days. 50 (50\%) of pathological discharges are seen in the $1^{\text {st }}$ decade of start of sexual activity i.e., in 21-30 years age group followed by 20 (20\%) in 31-40 years group and 8 $(8 \%)$ in more than 40 years age group.

\section{CONCLUSION}

Provision of information on Sexual and Reproductive Health (SRH) services in early years of starting of sexual journey may help in reduction of STIs/RTIs in reproductive populations. Since isolated and mixed infections are being the causes of vaginal discharge, the utilisation of available minimal laboratory services may help in provision of specific treatment. In the absence of laboratory, the syndromic management of vaginal discharge is highly recommended.

\section{KEYWORDS}

Vaginal Discharge, Bacterial Vaginosis, Candidiasis, Trichomoniasis, Candidal Vaginitis, Trichomonal Vaginitis, High Risk Group.

HOW TO CITE THIS ARTICLE: Ananthula VK, Prasad JVDS, Katikala S, et al. Clinical and aetiological pattern of vaginal discharge in patients attending STD clinic of a tertiary hospital. J. Evolution Med. Dent. Sci. 2017;6(65):4741-4745, D0I: 10.14260/Jemds/2017/1027

\section{BACKGROUND}

As the lower genital tract is directly exposed to the external environment, it is subjected to various infections and inflammations, which may remain localised or may progress to other areas such as the endometrium, fallopian tubes, peritoneal cavity and, less likely, the ovaries ${ }^{1}$. Genitourinary

Financial or Other, Competing Interest: None.

Submission 09-07-2017, Peer Review 02-08-2017,

Acceptance 08-08-2017, Published 14-08-2017.

Corresponding Author:

Dr. Prasad J. V. D S,

Associate Professor of STD/DVL,

Department of DVL (OP. No. 222),

$1^{\text {st }}$ Floor, OP Block, Osmania General Hospital,

Afzal gunj, Hyderabad-500013,

Telangana.

E-mail:drjvdsp@gmail.com

DOI: $10.14260 /$ jemds $/ 2017 / 1027$ tract infections are among the most frequent disorders for which patients seek care from a health care worker. By understanding the pathophysiology of these diseases and having an effective approach to their diagnosis, clinicians can institute appropriate antimicrobial therapy to treat these conditions and reducing long-term sequelae. ${ }^{2}$ Vaginitis is a commonly encountered complaint among women of reproductive age group. Vaginal discharge is a considerable problem for many women causing discomfort, anxiety affecting women's quality of life and consuming considerable resources. Some vaginal discharges are normal and can vary with age, use of contraceptives, menstrual cycle and with the oestrogen level. ${ }^{3}$

The vaginal flora is a dynamic ecosystem that can be easily altered. The following are the most frequently encountered causes of vaginal discharge. ${ }^{3}$ 
- Physiological-Premenarche, Preovulatory, Premenstrual, Sexual activity, Pregnancy, Lactation.

- Pathological vaginitis - Bacterial vaginosis, vaginal candidiasis, vaginal trichomoniasis, desquamative inflammatory vaginitis, toxic shock syndrome.

- Atrophic vaginitis - Chlamydia trachomatis, Neisseria gonorrhoea.

- Uterine sepsis - Neoplasm, psychosomatic vaginitis.

There are four causes of vaginal discharges which cover almost $95 \%$ of cases. These are Bacterial Vaginosis, Candidal Vulvovaginitis, Trichomoniasis and normal physiological discharge. The modern management of vaginal discharge demands a specific diagnosis, which is a combination of naked eye examination plus laboratory workup. ${ }^{3}$

If a proper diagnosis is made, instituting appropriate antimicrobial therapy will prevent long-term sequelae. This has indicated the need to take up this study of clinical and aetiological correlation in Vaginitis. The annual incidence of sexually transmitted diseases (STDs) in India is estimated as 5 percent i.e. approximately 40 million new infections occur every year. Prevalence of vaginal discharge in India is $30 \%$ and in Delhi it is $29.9 \%{ }^{4}$

\section{Aims and Objectives}

To understand the association between the type of vaginal discharge, its clinical features, organisms associated with the discharge and their prevalence in reproductive age women.

\section{MATERIALS AND METHODS}

A descriptive (prospective) study was undertaken over a period of 12 months from January 2015 to December 2015 in STD Clinic, Dept. of DVL, Osmania Medical College \& Osmania General Hospital, Hyderabad, Telangana State, India.

\section{Study Population}

A total of 100 women in reproductive age with the complaints of vaginal discharge were eligible and consented for the study in the study period after administering inclusion and exclusion criteria.

\section{Inclusion Criteria}

1. Sexually active reproductive age group women between 15-50 years presenting to the STD Clinic with complaints of Vaginal Discharge associated with or without other symptoms.

2. Willing to be part of the study with informed consent.

\section{Exclusion Criteria}

1. Not willing to be part of study.

2. Who had received systemic antibiotic therapy, steroids or local vaginal antimicrobial therapy within the preceding month.

3. Premenarchial Girls, Girls/women who have not started sexual activity, Pregnant \& Lactating women, Postmenopausal women, women with Genital or cervical malignancy and on treatment.

4. Women in menstrual period at the time of visit.

\section{Method of Study}

A consecutive sampling method with zero intervals was followed in the consenting order. A detailed clinical, personal and sexual history of the patient was taken; followed by performing external and internal examination with necessary sample collection for investigations.

\section{RESULTS}

The present study aims at determining clinical features \& aetiological agents of vaginal discharge in women attending STD Clinic, Dept. of DVL, Osmania Medical College/Osmania General Hospital, Hyderabad, TS. A total of 100 consented eligible women aged between 15-50 years were studied.

\begin{tabular}{|c|c|c|c|c|c|c|c|c|c|c|c|c|c|c|c|c|c|}
\hline \multirow[t]{2}{*}{$\begin{array}{l}\text { Age in } \\
\text { Years }\end{array}$} & \multirow{2}{*}{$\begin{array}{l}\text { No. } \\
\text { (n) }\end{array}$} & \multicolumn{2}{|c|}{$\begin{array}{c}\text { Normal } \\
\text { Vaginal } \\
\text { Flora }\end{array}$} & \multicolumn{2}{|c|}{$\begin{array}{l}\text { Bacterial } \\
\text { Vaginosis } \\
\text { (BV) }\end{array}$} & \multicolumn{2}{|c|}{$\begin{array}{l}\text { Candidal } \\
\text { Vaginitis } \\
\text { (CV) }\end{array}$} & \multicolumn{2}{|c|}{$\begin{array}{c}\text { Trichomonal } \\
\text { Vaginitis (TV) }\end{array}$} & \multicolumn{2}{|c|}{$\begin{array}{c}\text { Mixed Inf } \\
(\mathrm{BV}+\mathrm{CV}+\mathrm{TV})\end{array}$} & \multicolumn{2}{|c|}{$\begin{array}{c}\mathrm{BV}+ \\
\mathrm{CV}\end{array}$} & \multicolumn{2}{|c|}{$\begin{array}{c}\text { BV+ } \\
\text { TV }\end{array}$} & \multicolumn{2}{|c|}{$\begin{array}{c}\text { CV+ } \\
\text { TV }\end{array}$} \\
\hline & & (n) & $\%$ & (n) & $\%$ & (n) & $\%$ & (n) & $\%$ & (n) & $\%$ & (n) & $\%$ & (n) & $\%$ & (n) & $\%$ \\
\hline$<21$ & 09 & 3 & 3 & 2 & 2 & 2 & 2 & 1 & 1 & 1 & 1 & 1 & 1 & 0 & 0 & 0 & 0 \\
\hline $21-30$ & 56 & 6 & 6 & 21 & 21 & 13 & 13 & 7 & 7 & 9 & 9 & 6 & 6 & 2 & 2 & 1 & 1 \\
\hline $31-40$ & 24 & 4 & 4 & 10 & 10 & 2 & 2 & 5 & 5 & 3 & 3 & 2 & 2 & 1 & 1 & 0 & 0 \\
\hline$>40$ & 11 & 3 & 3 & 4 & 4 & 2 & 2 & 0 & 0 & 2 & 2 & 1 & 1 & 1 & 1 & 0 & 0 \\
\hline Total & 100 & 16 & 16 & 37 & 37 & 19 & 19 & 13 & 13 & 15 & 15 & 10 & 10 & 4 & 4 & 1 & 1 \\
\hline
\end{tabular}

In the present study, a total of 16 women $(16 \%)$ had normal physiological discharge but the quantity and timing with menstrual cycle is the concern for the women to misinterpret it as pathological discharge and attending the hospital. It is observed that with increasing age, the women are able to distinguish between these two, with which the lesser number is seen with advancing age.

Isolated cases of Bacterial Vaginosis (BV) is seen in 37 women (37\%), however, as part of mixed infection BV is present in 14 women (14\%), combined together totalling to $51(51 \%)$.
Isolated cases of Candidal Vaginitis (CV) is seen in 19 women (19\%), as part of mixed infection CV is seen in 11 women (11\%), together totalling to $30(30 \%)$.

Isolated cases of Trichomonal Vaginitis (TV) is seen in 13 women $(13 \%)$, as part of mixed infection TV is seen in 5 women (5\%), together totalling to $18(18 \%)$.

One common finding is highest number of discharges are seen in the initial part of onset of sexual and reproductive activity age i.e., between 21 to 30 years. The types of discharges seen are both physiological and pathological. However, as the age advances, the numbers of infections including physiological discharges are coming down. This phenomenon may be attributable to increased awareness on 
sexual and reproductive health (SRH) through various means capacitating the women to follow sexual and reproductive hygiene and protect themselves through safer sex practices.
In the present study, there are 84 women diagnosed with either a single or mixed pathological vaginal discharges.

\begin{tabular}{|c|c|c|c|c|c|c|c|c|}
\hline $\begin{array}{c}\text { Age in } \\
\text { Years }\end{array}$ & \multicolumn{2}{|c|}{$\begin{array}{c}\text { No. of Path. } \\
\text { Vag. Discharge }\end{array}$} & $\begin{array}{c}\text { Total Bacterial Vaginosis } \\
\text { (BV) } \\
\text { (Isolated + Mixed) }\end{array}$ & $\begin{array}{c}\text { Total Candidal Vaginitis } \\
\text { (CV) } \\
\text { (Isolated + Mixed) }\end{array}$ & $\begin{array}{c}\text { Total Trichomonal Vaginitis } \\
\text { (TV) } \\
\text { (Isolated + Mixed) }\end{array}$ \\
\hline & $(\mathrm{n})$ & $\%$ & $(\mathrm{n})$ & $\%$ & $(\mathrm{n})$ & $\%$ & $(\mathrm{n})$ & $\%$ \\
\hline$<21$ & 06 & 07.14 & $02+01=03$ & 06.0 & $02+01=03$ & 10.00 & $01+00=01$ & 05.56 \\
\hline $21-30$ & 50 & 59.53 & $21+08=29$ & 56.9 & $13+07=20$ & 66.67 & $07+03=10$ & 55.56 \\
\hline $31-40$ & 20 & 23.80 & $10+03=13$ & 25.5 & $02+02=04$ & 13.33 & $05+01=06$ & 33.33 \\
\hline$>40$ & 08 & 09.53 & $04+02=06$ & 11.8 & $02+01=03$ & 10.00 & $00+01=01$ & 05.56 \\
\hline Total & $\mathbf{8 4}$ & $\mathbf{1 0 0}$ & $\mathbf{5 1}$ & $\mathbf{1 0 0}$ & $\mathbf{3 0}$ & $\mathbf{1 0 0}$ & $\mathbf{1 8}$ & $\mathbf{1 0 0}$ \\
\hline \multicolumn{7}{|c|}{ Table 2. Age Wise Distribution of Pathological Vaginal Discharge in Women } \\
\hline
\end{tabular}

Among the study group, majority of pathological discharges are seen in the age group of 21-30 years (59.53\%) followed by $31-40$ years $(23.80 \%)$. The same pattern is seen across all 3 infections viz., for Bacterial Vaginosis 56.9\% \& 25.5\%, for Candidal Vaginitis $66.67 \%$ \& $13.33 \%$ and for Trichomonas Vaginitis 55.56\% \& 33.33\%.

Among the clinical features of Bacterial Vaginosis (BV), homogenous discharge is the most common feature (94.11\%), followed by odour (70.59\%), dysuria (39.21\%) and pruritus (11.76\%). Among the clinical features of Candidiasis (CV), most common feature is curdy white discharge
(53.33\%) followed by pruritus $(40.0 \%)$, burning sensation (33.33\%), dysuria (16.66\%) and dyspareunia (16.66\%). Among the clinical features of Trichomoniasis (TV), most common feature is frothy discharge $(77.77 \%)$ followed by pruritus $(66.66 \%)$, odour $(44.44 \%)$ and dysuria $(22.22 \%)$.

Table 3. Distribution of Discharges in High Risk Group The women are categorised as high risk based on having more than one sexual partner in last 30 days and used condom inconsistently.

\begin{tabular}{|c|c|c|c|c|c|c|c|c|c|c|}
\hline $\begin{array}{l}\text { Age in } \\
\text { Years }\end{array}$ & $\begin{array}{c}\text { Total } \\
\text { No. }\end{array}$ & HRG No. & $\begin{array}{c}\text { Normal } \\
\text { Vaginal } \\
\text { Flora }\end{array}$ & $\begin{array}{c}\text { Bacterial } \\
\text { Vaginosis } \\
\text { (BV) }\end{array}$ & $\begin{array}{c}\text { Candidal } \\
\text { Vaginitis } \\
\text { (CV) }\end{array}$ & $\begin{array}{r}\text { Trichomonal } \\
\text { Vaginitis (TV) }\end{array}$ & $\begin{array}{c}\text { Mixed Inf } \\
(\mathrm{BV}+\mathrm{CV}+\mathrm{TV})\end{array}$ & $\mathrm{BV}+\mathrm{CV}$ & $\begin{array}{c}\text { BV+ } \\
\text { TV }\end{array}$ & $\mathrm{CV}+\mathrm{TV}$ \\
\hline$<21$ & 09 & 03 & 1 & 1 & 0 & 0 & 1 & 1 & 0 & 0 \\
\hline $21-30$ & 56 & 23 & 0 & 9 & 5 & 3 & 6 & 3 & 2 & 1 \\
\hline $31-40$ & 24 & 13 & 1 & 5 & 2 & 3 & 2 & 2 & 0 & 0 \\
\hline$>40$ & 11 & 05 & 1 & 2 & 1 & 0 & 1 & 0 & 1 & 0 \\
\hline Total & 100 & 44 & 3 & 17 & 8 & 6 & 10 & 6 & 3 & 1 \\
\hline \multicolumn{11}{|c|}{ Table 3} \\
\hline
\end{tabular}

HRG constitutes 44 (44\%) in total attendees with Vaginal Discharge. It is observed that, as the age is increasing the number of women in high risk category are decreasing with which the risk of STIs/RTIs. The decrease in partner number can be attributable to failure of attracting the male clients and the men preferring the younger women, etc. Accordingly, all types of vaginal discharges have followed decrease in number as the age is increasing in the HRG.
Bacterial Vaginosis (BV) is the most common cause of discharge in 26 of 44 constituting 59\%, followed by Candidiasis in 15 (34\%), Trichomoniasis in 10 (22.72\%) and mixed infections in $10(22.72 \%)$. The higher prevalence of BV can be attributable to multiple and varied partners of HRGs, inconsistent condom use, poor genital and sexual hygiene, poor nutritional status, etc.

\begin{tabular}{|c|c|c|c|c|c|c|c|c|c|c|}
\hline $\begin{array}{l}\text { Age in } \\
\text { Years }\end{array}$ & $\begin{array}{c}\text { Total } \\
\text { No. }\end{array}$ & HIV No. & $\begin{array}{c}\text { Normal } \\
\text { Vaginal } \\
\text { Flora }\end{array}$ & $\begin{array}{c}\text { Bacterial } \\
\text { Vaginosis } \\
\text { (BV) }\end{array}$ & $\begin{array}{c}\text { Candidal } \\
\text { Vaginitis } \\
\text { (CV) }\end{array}$ & $\begin{array}{r}\text { Trichomonal } \\
\text { Vaginitis (TV) }\end{array}$ & $\begin{array}{c}\text { Mixed } \\
\text { Infections } \\
\text { (BV+CV+TV) }\end{array}$ & $\begin{array}{c}\text { BV+ } \\
\text { CV }\end{array}$ & $\begin{array}{c}\text { BV+ } \\
\text { TV }\end{array}$ & $\begin{array}{l}\text { CV+ } \\
\text { TV }\end{array}$ \\
\hline$<21$ & 09 & 03 & 0 & 0 & 1 & 1 & 1 & 1 & 0 & 0 \\
\hline $21-30$ & 56 & 22 & 1 & 11 & 4 & 2 & 4 & 2 & 1 & 1 \\
\hline $31-40$ & 24 & 11 & 0 & 6 & 1 & 3 & 1 & 1 & 0 & 0 \\
\hline$>40$ & 11 & 05 & 1 & 1 & 1 & 0 & 2 & 1 & 1 & 0 \\
\hline Total & 100 & 41 & 2 & 18 & 7 & 6 & 8 & 4 & 2 & 1 \\
\hline
\end{tabular}

HIV seropositivity is seen in 41 women (41\%) among total study group population. Only 2 of 41 (4.88\%) seropositive women are carrying normal vaginal flora in the studied population. Bacterial Vaginosis (BV) is most common in 24 of 41 (58.53\%), followed by candidiasis in 12 of 41 (29.26\%), Trichomoniasis in 9 of 41 (21.95\%). Mixed infections are seen in 8 of 41 (19.51\%). HIV serostatus is one strong influencing factor in disturbing the vaginal ecosystem and results in increased risk of both STIs/RTIs. The present study also shows higher prevalence of BV and CV due to disturbed protective mechanisms at genital level. 
In the present study, an Amsel criterion is seen in 43 cases of Bacterial Vaginosis and Nugent's score is positive in 51 cases. Candidiasis was isolated using Sabouraud's Dextrose Agar (SDA) in 30 cases, where in the organism is seen by using KOH Mount in 24 cases and by Gram stain in 12 cases. Trichomoniasis was isolated in 18 cases by using Kupferberg medium, 16 cases by Wet mount, 13 by Pap smear and 8 by Giemsa stain.

\section{DISCUSSION}

A clinical and microbiological evaluation of vaginal discharge was carried out on 100 eligible and consented women aged between 15-55 years attending STD OP, Dept. of DVL, Osmania Medical College/Osmania General Hospital, Hyderabad after meeting inclusion and exclusion criteria.

\section{The following Observations are made Age Wise Incidence of Vaginitis}

Vaginitis was found to be most prevalent in the age group of $21-30$ years $(56 \%)$ and least in $<21$ years age group (9\%). J. W. Mahadani (1998) showed similar incidence $(66.45 \%)$ in the age group 21-30 years. ${ }^{5}$ In the present study across all age groups, 21-30 years age group patients showed 56.9\% prevalence among Bacterial Vaginosis, $66.67 \%$ prevalence among Candidiasis and $55.56 \%$ prevalence among Trichomoniasis. Mixed infections are also more common $(60 \%)$ in 21-30 years age group. Study of Muvunyi et al ${ }^{6}$ showed that bacterial vaginosis was found in $52.8 \%$ in the age group of 21-30 years. The study of Ako et al supports that vaginal candidiasis occurs most frequently in the age group of 21-30 years. ${ }^{7}$ Welbeck A. Twum et al showed prevalence of T. vaginalis in 18 to 31 (68.15\%) in females. ${ }^{8}$

\section{Sexual Behaviour}

In the present study, Bacterial vaginosis is seen in $40.90 \%$ of total high-risk group infections. Marrazzo et al and Bradshaw CS et al found BV is the most prevalent vaginal infection particularly in countries with high HIV prevalence.9,10 In the present study, Candidiasis is seen in $19.69 \%$ of total high-risk group infections. Among the total candidal infections, $68.42 \%$ are seen in high-risk group. Sebitloane HM et al showed HIV infection as a risk factor for developing VVC. ${ }^{11}$

\section{Bacterial Vaginosis}

Among the patients diagnosed with Bacterial Vaginosis, clinical features suggestive of homogenous grey white discharge is seen in 48 patients (94.11\%) followed by odour in 36 patients $(70.59 \%)$, other symptoms like dysuria is seen in 20 patients $(39.21 \%)$, itching in 6 patients $(11.76 \%)$. Similar findings were observed by Charles $\mathrm{H}$ Livengood et al. ${ }^{12}$ In the present study, dysuria is seen in $36.36 \%$ of bacterial vaginosis patients. After microbiological evaluation, these patients were showing mixed infections with candidiasis \& Trichomoniasis. Amsel $\mathrm{R}$ et al observed BV alone does not cause dysuria, dyspareunia, pruritus, burning, or vaginal inflammation (erythema, oedema). ${ }^{13}$ The presence of these symptoms suggests mixed vaginitis (Symptoms due to two pathogens). ${ }^{14}$

In our study, $37 \%$ of the women were presumptively diagnosed as suffering from Bacterial vaginosis. Similar rates have been observed by V. O. Rotimi et al (1991) 38.9\%.15
In this study, Amsel criteria diagnosed $43 \%$ of women suffering from bacterial vaginosis. Therefore, the sensitivity and specificity of Amsel criteria were $72.5 \%$ and $87.7 \%$ respectively. Among the four Amsel criteria, clue cells in Gram stain had the highest sensitivity of $88.2 \%$ and a positive whiff test had $100 \%$ specificity. Clue cells were absent in $11.8 \%$ of the bacterial vaginosis cases. While J W Mahadani (1998) found clue cells to be $100 \%$ sensitive and $95.25 \%$ specific. ${ }^{5}$ Modak et al (2011) found it to be $100 \%$ sensitive and $76 \%$ specific. ${ }^{16}$ Brijinder K. Gupta (1998) noted clue cells in only $61 \%$ of the cases symptomatic for bacterial vaginosis. $^{17}$ In this study, presence of clue cells correlated best with a positive diagnosis by Nugent's score while thin homogenous discharge had the lowest correlation. This is similar to the findings of Modak et al (2011). ${ }^{16}$

\section{Candidiasis}

In this study, among 30 patients with Candidal Vaginitis, 16 patients gave history of discharge and in whom discharge was observed on examination (53.33\%). Other symptoms like vaginal itching were observed in 12 patients (40\%), burning sensation in 10 patients (33.33\%), dyspareunia and dysuria in 5 patients (16.66\%). Stanley et al (1975) observed complaints of discharge in $42 \%$, irritation in $15 \%$ of patients. ${ }^{18}$ In this study, prevalence of candidiasis as a single cause of discharge is seen in $19 \%$. Mixed infections with Bacterial vaginosis and Trichomoniasis are seen in $11 \%$. Similar incidence (17.8\%) reported by Di Bartolomeo et al (2002). ${ }^{19}$ Out of 100 cases Candida was isolated in $30 \%$ of the patients by Gram stain and culture on SDA.

\section{Trichomonas Vaginalis}

In this study of patients with Trichomoniasis, Greenish yellow discharge was seen in $77.77 \%$, itching in $66.66 \%$, Odour in $44.44 \%$, dysuria in $22.22 \%$. Similar findings were reported by Thomason in 1988 with vaginal discharge in $78 \%$ of Trichomoniasis patients. ${ }^{20}$ Swygard and colleagues (2004) observed vaginal discharge as the most common presenting complaint followed by pruritus and dysuria. ${ }^{21}$

The methods used for diagnosis were wet mount, Giemsa stain, Pap stain and culture on Kupferberg medium. Of the 100 cases, $18 \%$ were found to be harbouring $\mathrm{T}$. vaginalis by culture. The prevalence of $\mathrm{T}$. vaginalis infection reported in the present study is almost equivalent with that reported by Kaydos et al (2002) 16.7\%.22 A slightly lower prevalence was reported by Pillay et al (2004) $12.6 \%{ }^{23} \mathrm{~A}$ high prevalence of $47 \%$ was reported by Watt et al (1986). ${ }^{24}$

In our study, Giemsa stain detected 8 cases with $44.44 \%$ sensitivity; Pap stain detected 13 cases with $72.22 \%$ sensitivity. Wet mount detected 16 cases out of 18 that is $88.8 \%$ sensitivity which is similar to that reported by Thomasen et al (1988) 86\%.20 A very low sensitivity has been reported by Watt et al (1986) 36.9\%.24 Remaining 2 cases which were missed by wet mount were detected by culture. In this study, $100 \%$ cases were found by culture. Considering culture as the gold standard, the prevalence of $\mathrm{T}$. vaginalis infection was found to be $18 \%$.

\section{CONCLUSION}

Present study shows Bacterial Vaginosis was the highest (51\%) followed by Vaginal Candidiasis (30\%) and Trichomoniasis (18\%) and mixed infections are seen in $15 \%$ 
in the studied population with normal vaginal flora seen in 16 (16\%). The prevalence of vaginal discharge was more common in 21-30 years and low in $<21$ years. Incorporating the sexual and reproductive health education in academic curriculum at school level is very important. With practise of aetiological diagnosis by minimal laboratory support, the undertreatment or overtreatment can be corrected. However, in the absence of lab support, syndromic management of vaginal discharge by following the flow charts developed by each nation/WHO is recommended.

\section{REFERENCES}

[1] Nuovo GJ. Microorganisms of cervix and vagina. In: Cytopathology of the lower female genital tract: an integrated approach. Philadelphia: Lippincott Williams and Wilkins 1994:341-75.

[2] Soper DE. Genitourinary infections and sexually transmitted diseases. In: Berek SJ, ed. Novak's gynecology. $13^{\text {th }}$ edn. Philadelphia: Lippincott Williams and Wilkins 2002:453-70.

[3] Khan SA, Amir F, Altaf S, et al. Evaluation of common organisms causing vaginal discharge. J Ayub Med Coll Abbottabad 2009;21(2):90-3.

[4] National Family Health Survey 2 (NFHS II). Mumbai: International Institute for Population Sciences 1999:307-14.

[5] Mahadani JW, Dekate RR, Shrikhande AV. Cyto diagnosis of discharge per vaginum. Indian J Pathol Microbiol 1998;41(4):403-11.

[6] Muvunyi CM, Hernandez TC. Prevalence of bacterial vaginosis in women with vaginal symptoms in south province, Rwanda. Afr J Cln Exper Microbiol 2009;10(3):156-63.

[7] Ako-Nai AK, Kassim O0, Adeniran MO, et al. Study of urinary tract infections at Ile-Ife, Nigeria. East African Medical Journal 1993;70(1):10-14.

[8] Twum WA, Opoku-Okrah C, Tay SCK, et al. Trichomonas vaginalis cases presenting at the Komfo Anokye teaching hospital, Ghana over a period of 11 years: 1994 to 2004. International Journal of Medicine and Medical Sciences 2014;6(5):140-5.

[9] Marrazzo J. Bacterial vaginosis. Current Treatment Options in Infectious Diseases 2003;5:63-8.

[10] Bradshaw CS, Morton AN, Garland SM, et al. Higherrisk behavioral practices associated with bacterial vaginosis compared with vaginal candidiasis. Obstetrics \& Gynecol 2005;106(1):105-14.

[11] Sebitloane HM, Moodley J, Esterhuizen TM. Pathogenic lower genital tract organisms in HIV-infected and uninfected women, and their association with postpartum infectious morbidity. S Afr Med J 2011;101(7):466-9.
[12] Livengood CH. Bacterial vaginosis: an overview for 2009. Rev Obstet Gynecol 2009;2(1):28-37.

[13] Amsel R, Totten PA, Spiegel CA, et al. Nonspecific vaginitis. Diagnostic criteria and microbial and epidemiologic associations. Am J Med 1983;74(1):1422.

[14] Livengood CH, Thomason JL, Hill GB. Bacterial vaginosis: diagnostic and pathogenetic findings during topical clindamycin therapy. Am J Obstet Gynecol 1990;163(2):515-20.

[15] Rotimi VO, Yakubu Z, Abudu 00, et al. Direct Gram's stain of vaginal discharge as a means of diagnosing bacterial vaginosis. J Med Microbiol 1991;35(2):103-6.

[16] Modak T, Arora P, Agnes C, et al. Diagnosis of bacterial vaginosis in cases of abnormal vaginal discharge: comparison of clinical and microbiological criteria. J Infect Dev Ctries 2011;5(5):353-60.

[17] Gupta BK, Kumar R, Sofat R, et al. The role of Gardnerella vaginalis in nonspecific vaginitis in intra uterine contraceptive device users. Indian J Pathol Microbiol 1998;41(1):67-70.

[18] De Hurley R, Stanley VC. Microbial flora of the lower genital tract during pregnancy: relationship to morbidity. J Clin Pathol 1975;28(9):731-5.

[19] Di Bartolomeo S, Fermepin MR, Sauka DH, et al. Prevalence of associated microorganisms in genital discharge, Argentina. Rev Saude Publica 2002;36(5):545-52.

[20] Thomason JL, Gelbart SM, Wilcoski LM, et al. Proline aminopeptidase activity as a rapid diagnostic test to confirm bacterial vaginosis. Obstet Gynecol 1988;71:607-11.

[21] Swygard H, Sena AC, Hobbs MM, et al. Trichomoniasis: clinical manifestations, diagnosis and management. Sex Transm Infect 2004;80(2):91-5.

[22] Kaydos SC, Swygard H, Wise SL, et al. Development and validation of a PCR-based enzyme-linked immunosorbent assay with urine for use in clinical research settings to detect Trichomonas vaginalis in women. J Clin Microbiol 2002;40(I):89-95.

[23] Pillay A, Lewis J, Ballard RC. Evaluation of XenoStrip$\mathrm{Tv}$, a rapid diagnostic test for Trichomonas vaginalis infection. J Clin Microbiol 2004;42(8):3853-6.

[24] Watt RM, Philip A, Wos SM, et al. Rapid assay for immunological detection of Trichomonas vaginalis. J Clin Microbiol 1986;24(4):551. 